NBER WORKING PAPER SERIES

\title{
A COMMON CURRENCY: EARLY U.S. MONETARY POLICY AND THE TRANSITION TO THE DOLLAR
}

\author{
Peter L. Rousseau \\ Working Paper 10702 \\ http://www.nber.org/papers/w10702
}

NATIONAL BUREAU OF ECONOMIC RESEARCH

1050 Massachusetts Avenue

Cambridge, MA 02138

August 2004

The author thanks Michael D. Bordo, Benjamin Chabot, William K. Hutchinson, Hugh Rockoff, Richard Sylla, David Weiman, Robert E. Wright, and participants at the 2003 meetings of the Economic History Association, the 2004 meetings of the American Economic Association, and the Economic History Seminar at the University of Michigan for helpful comments and discussions. The views expressed herein are those of the author(s) and not necessarily those of the National Bureau of Economic Research.

(C2004 by Peter L. Rousseau. All rights reserved. Short sections of text, not to exceed two paragraphs, may be quoted without explicit permission provided that full credit, including $($ ) notice, is given to the source. 
A Common Currency: Early U.S. Monetary Policy and the Transition to the Dollar Peter L. Rousseau NBER Working Paper No. 10702

August 2004

JEL No. E44, N11, N21

\section{ABSTRACT}

The transition of the U.S. money supply from the mixture of paper bills of credit, certificates, and foreign coins that circulated at various exchange rates with the British pound sterling during the colonial period to the unified dollar standard of the early national period was rapid and had farreaching consequences. This paper documents the transition and highlights the importance of this standardization in bringing order to the nation's finances and in facilitating the accumulation and intermediation of capital. It describes how the struggle of the colonies to maintain viable substitutes for hard money set the stage for the financial leaders of the Federalist period, led by Alexander Hamilton, to settle upon the dollar, attach it to a convertible metallic base, and create a national Bank that issued notes denominated in the new monetary unit. It also presents recently-constructed estimates of the U.S. money stock for 1790-1820 and relates them to measures of the nation's early modernization.

Peter L. Rousseau

Department of Economics

Vanderbilt University

Box 1819 Station B

Nashville, TN 37235

and NBER

peter.1.rousseau@vanderbilt.edu 


\section{Introduction}

The U.S. economy's transition to the dollar early in the Federal period (1790-1811) marks the emergence of the monetary system that for the most part exists today. With it came a central bank, the start of modern banking and securities markets, and newly-found confidence among investors in the ability of the young nation to service its financial obligations. The importance of these events for the nation's early growth has only recently begun to receive the attention that it warrants (e.g., Sylla 1998; Rousseau and Sylla 1999, 2004). In some respects, however, the impact of Alexander Hamilton's financial "revolution" on real activity should come as little surprise given the monetary conditions that existed in the years leading up to the Federal Constitution of 1789. At that time unbacked issues of fiat money that helped to finance the American victory in the Revolutionary War gave way to an inflationary spiral, debt depreciation, and a scarcity of real money balances. The need to unify the nation's currency and to restore the public's confidence in it weighed heavily in the minds of the forefathers as they drafted a Constitution that forbade emissions of paper money by individual states in favor of committing to a securely-backed transactions asset.

The decision to forbid issues of paper money by states was based on experience. The colonial money stock, essentially a combination of state-issued bills of credit and foreign coins, functioned adequately at times in colonies such as Pennsylvania and New York, but was hardly ever more than a temporary remedy for hardships imposed by wars and the extractive policies of the mother country. When the system functioned badly, as it did at various times in New England and the Carolinas, it caused serious difficulties for individuals involved in market transactions.

Scholars in the late 19th century such as A. M. Davis tended to emphasize the more severe malfunctions of colonial monetary arrangements when engaged in debates with contemporaries about expanding the money supply (see the discussion in Ferguson 1953, pp. 153-54), but in doing 
so probably over-stressed the long-run importance of these negative events. Later historians such as Brock (1941, 1992), Ferguson (1953) and Perkins (1994) have taken a more moderate stance, commenting instead on how surprisingly well the colonial monetary arrangements seemed to work much of the time. None of these scholars, however, have contended that the young U.S. economy would have been better off had it retained state-issued bills of credit into the 19th century.

While recognizing that the colonial experience with paper money was not entirely unsatisfactory, and perhaps even necessary given the challenges of financing wars, promoting agriculture, and providing a medium of exchange in the face of restrictions imposed by England on coinage and specie imports, in this paper I take a quantitative approach to documenting its deficiencies and the degree to which monetary conditions improved in the early Federal period. The transition to the dollar and all that came with it mattered because, over time, it succeeded in monetizing the modern sector of the U.S. economy. This was not possible in an era when colonial legislatures were unable to commit credibly to backing currency emissions.

A failure to monetize meant that a large portion of transactions occurred through barter, bookkeeping credit, and other informal means, and that transactions frictions were serious. These frictions held the level of economic development in the colonies below what might have been achieved in a location so rich in the fixed factors of production. When states issued paper money in quantities small enough that the public retained confidence in the underlying resolve to impose the taxes required for its redemption, paper money held its value against specie, the real money stock expanded and monetization proceeded. When issues became so large that the public began to question the commitment to redeem the bills, rightfully or not, depreciation quickly set in and monetization halted. Calomiris (1988) makes this same point, though focusing primarily on the depreciation of the federally-issued "continentals" issued to finance the War of Independence. 
Wright (2001) also comments on the under-monetization of the colonial economy using historical letters and other anecdotal evidence.

These ideas contrast with those advanced in Grubb (2003), which reinterprets the Constitution's ban on state issues as a successful attempt of powerful, moneyed interests to usurp state sovereignty. Michener and Wright (2003) have challenged this view by pointing to a number of factual and conceptual flaws that they find in Grubb's case. Rather than focus directly on this debate, however, which considers the political motivations of the key framers of the Federal Constitution, in this paper I will simply make a few quantitative observations which suggest that the transition to the dollar was a defining moment in modern U.S. growth. These observations are: 1) the colonial economy was inadequately monetized; 2) as a result, the colonial economy did not experience financial deepening; 3) the money stock and financial sector expanded rapidly in the early Federal period; and 4) this led to gains in financial depth over the nation's first 50 years. I will then show that monetization of the modern sector was central to this achievement.

\section{The Colonial Period}

\subsection{Features of the Colonial Money Supply}

In terms of economic indicators, the colonial period of American history is part of what scholars sometimes refer to as a statistical "dark age." Economic activity in this era is difficult to measure because many transactions did not involve an intermediate medium of exchange such as coins or paper money. Local, non pecuniary credit transactions and barter were common means of obtaining consumption goods, especially outside of the urban centers. And even though the colonies functioned under such arrangements, it is likely that transactions costs were higher than necessary and led to real losses in economic efficiency. The metallic stock that did exist was a collection of foreign coins, primarily the Spanish dollar or "piece of eight," with each coin valued at 
a local "pound" equivalent that varied from colony to colony. This metallic base, which most scholars speculate could not have accounted for more than 40 percent of the money stock on the eve of the Revolutionary War (see Smith 1985, 1992, and the sources cited therein), was insufficient to support all of the transactions for which it would have been convenient. ${ }^{1}$ It also had a tendency to flow into colonies that valued it more in terms of the local currency and out of colonies that valued it less. All the while, specie was under pressure to go abroad to settle trade deficits with England, and thus was rarely far from commercial interests. The crown prohibited the colonies from minting their own coins, and coins could not flow back from England in the course of trade because specie exports to the colonies were prohibited as well. These one-sided arrangements meant that the metallic currency was always under pressure and sensitive to fluctuations in the trade balance. It is against this backdrop that the colonies, starting with Massachusetts in 1690 (Brock, 1941, p. 18), experimented with issues of paper money. The money got into circulation as public payments for military operations and as direct loans to farmers by government land offices. The paper would retain its value because it was backed by future tax collections, meaning that the colonial governments would promise to accept the paper at some point (usually years later) at face value in payment of tax obligations. When colonial governments could credibly commit to doing this, their bills of credit had real economic value because, given the level of economic activity and population growth, their convenience in transactions allowed them to be absorbed without depreciation. As the first signs of suspicion or doubt about the steadfastness of this commitment arose, however, as they did in North Carolina and New England in the 1740s, the paper money would depreciate against specie, often to the point of worthlessness.

\footnotetext{
${ }^{1}$ Michener (2003) presents a contrasting view that specie probably made up a larger part of the Colonial money stock.
} 


\subsection{Bills of Credit per Capita}

The colonial experiences with rapid depreciation led all colonists to place some positive weight on the possibility that their currency might one day become worthless. This limited the volume of bills that colonial governments could issue. The more stable experiments with paper money in Pennsylvania, New York, and New Jersey avoided catastrophic depreciations because issues remained manageable. It does not follow from this, however, that these colonies had an optimal monetary arrangement. Rather, these colonies had great difficulty in monetizing. Figure 1 shows the per capita stock of paper money from 1710 to 1775 in these mid-Atlantic "successes" after converting to sterling equivalents. I made the conversions by dividing the amount of outstanding bills of credit by the total population of each colony, and multiplying the result by average annual sterling exchange rates. ${ }^{2}$

It may be surprising that Pennsylvania (given by the dashed line in Figure 1), often touted by scholars as the great example of currency finance at its best, saw its per capita stock of paper money fall steadily from 1724 until 1755 . It rose from 1755 to 1760 in the midst of the Seven-Years War, but then fell rapidly, reaching its lowest point in the pre-Independence period by 1773 . In 1750, bills per capita were about $£ 0.7$ (14 s.) in local Pennsylvania currency or $£ 0.4$ in sterling

${ }^{2}$ Bills of credit in circulation for Pennsylvania are from Brock (1992, table 6) as corrected by Ronald Michener. For New Jersey they are from Brock (1941, table VI, p. 93) for 1724-52, and from Brock (1992, table 5) for 1753-74. The amount of outstanding bills for New York are available on an annual basis after 1747 from Brock (1992, table 5). From 1709-47, Brock (1941, pp. 66-73) includes records of emissions, anticipated redemptions, and many actual redemptions. There are also a few benchmark estimates of the overall stock of bills. Using this information and linear interpolation for missing years in the time paths of individual issues and their retirements, I approximated the stock of bills for New York during this period. Colonial populations are from Bureau of the Census (1975, p. 1168, series Z-9, Z-10, and Z-11), and use constant growth rates to interpolate between decadal observations. Sterling exchange rates are annual averages of local currency per $100 £$ sterling from McCusker (1978: table 3.5, pp. 162-67 for New York; table 3.6, pp. 172-73 for New Jersey; and table 3.7, pp. 183-88 for Pennsylvania), using linear interpolation to fill in between occasional missing observations. 


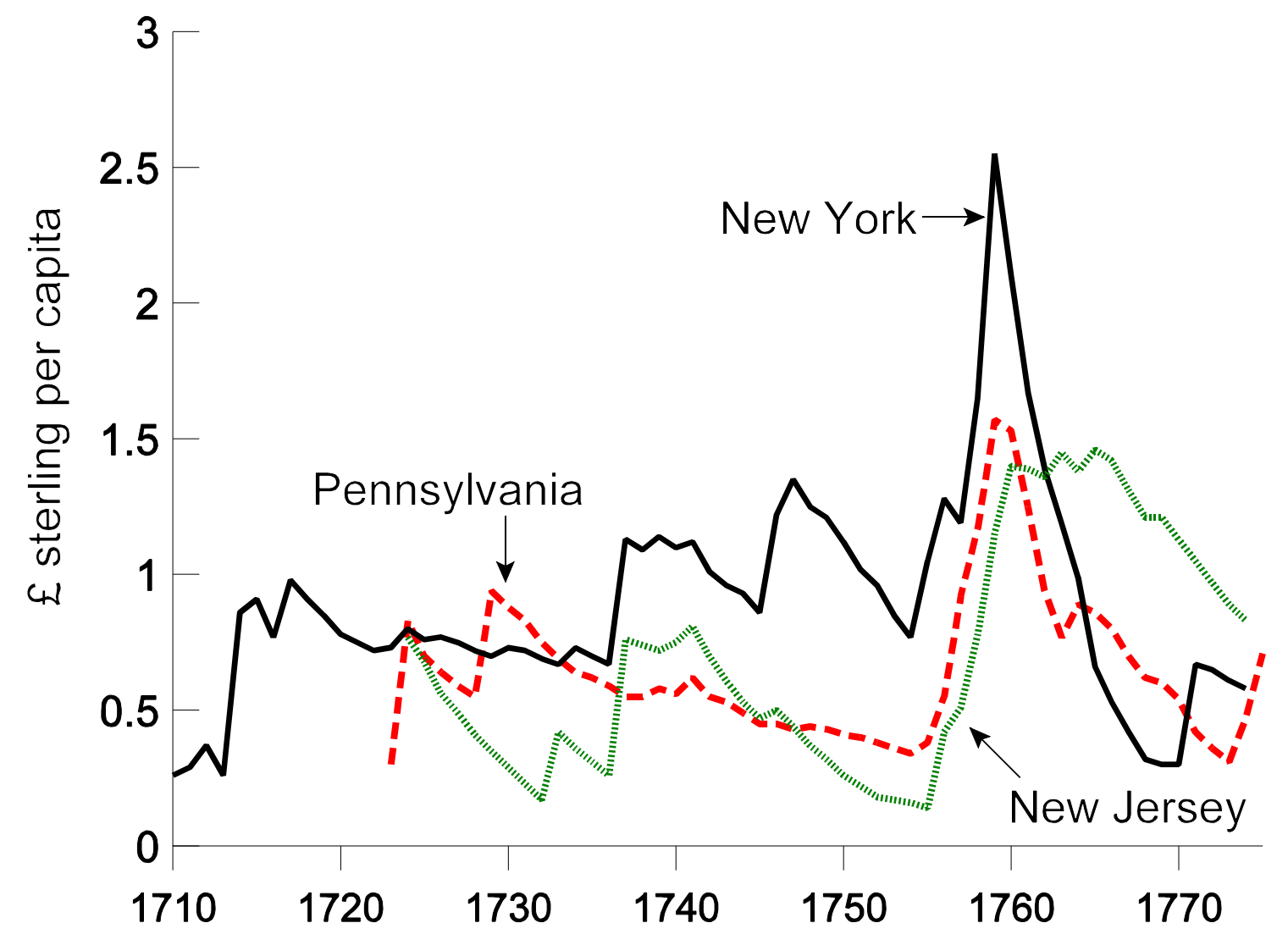

Figure 1. Bills of Credit Outstanding per Capita in the Mid-Atlantic Colonies, 1710-1775.

equivalent. This amount could purchase, for example, using December prices from Cole (1938, p. 31-32), one gallon of rum (3 s.), one bushel of wheat (4.5 s.), one bushel of corn ( $2.5 \mathrm{~s}$.$) , and 2$ lbs. of cotton ( $2 \mathrm{~s}$.). In other words, the stock of paper money could have supported purchases of staple goods if it had changed hands frequently. Yet any savings would have lowered velocity, and the colonists were faced with other cash expenses such as building materials, capital goods, and farm maintenance costs.

A comparison of bills of credit per capita in Pennsylvania with England's per capita money stock further suggests that colonial economy was under-monetized. Cameron (1967) estimates England's M2 in 1750 at about 52 million in 1790 sterling. Since England's population was about 6 
million in 1750 and the consumer price index $(1790=1)$ was 0.779 , real money per capita was about $£ 6.80$ - much more than the $£ 0.4$ sterling equivalent for Pennsylvania. Even allowing for the generous possibility that specie accounted for 40 percent of Pennsylvania's money stock, the per capita money stock (paper money plus specie) could therefore not have exceeded $£ 0.67$ in sterling equivalent. It is true that many English citizens could use money as a form of savings more easily than the colonists due to the presence of a still small but rapidly expanding set of country banks, and that their consumption possibilities in the market economy were wider, but it is hard to imagine that these differences would have created a tenfold increase in the demand for money.

To make another comparison, 14 Pennsylvania shillings in 1750 would be worth about $\$ 38$ U.S. at the end of $2003 .{ }^{3}$ This amount of currency would be insufficient for an individual in the United States today to complete weekly cash purchases without using checks and/or credit cards (i.e., instruments of a modern financial system), even if consumption possibilities were limited to those available to the colonists. Indeed, the U.S. monetary base (currency and coin) now exceeds $\$ 2,000$ per person, and M1 (currency and checking deposits) exceeds $\$ 4,000$ per person.

The per capita stock of paper money in New Jersey, given by the dotted line in Figure 1, was more variable than that of Pennsylvania but has the same downward trend from 1725 to the start of the Seven-Years War. New York, given by the solid line, was more successful in monetizing between 1710 and 1760 , but bills of credit per capita were still only $£ 1.1$ in sterling equivalent by 1750 . These figures all suggest, given reasonable conjectures about velocity of

${ }^{3}$ I obtained this estimate by multiplying the sterling equivalent of $£ 0.4$ in 1750 by the 6.15 percent total increase in English consumer prices between 1750 and 1900, converting to 1900 U.S. dollars using the exchange rate of $\$ 4.87 / £$, and multiplying the result by the 18 -fold increase in U.S. prices that occurred between 1900 to 2003. I built a continuous index of English prices by ratiosplicing the Schumpeter-Gilboy index for 1750-1819 (U.S. Bureau of the Census, table 14.1.B, pp. 719-20) with Rousseaux's index for 1820-45 (table 14.3, p. 722) and the Sauerbeck-Statist index for 1846-1900 (table 14.4, p. 725). 


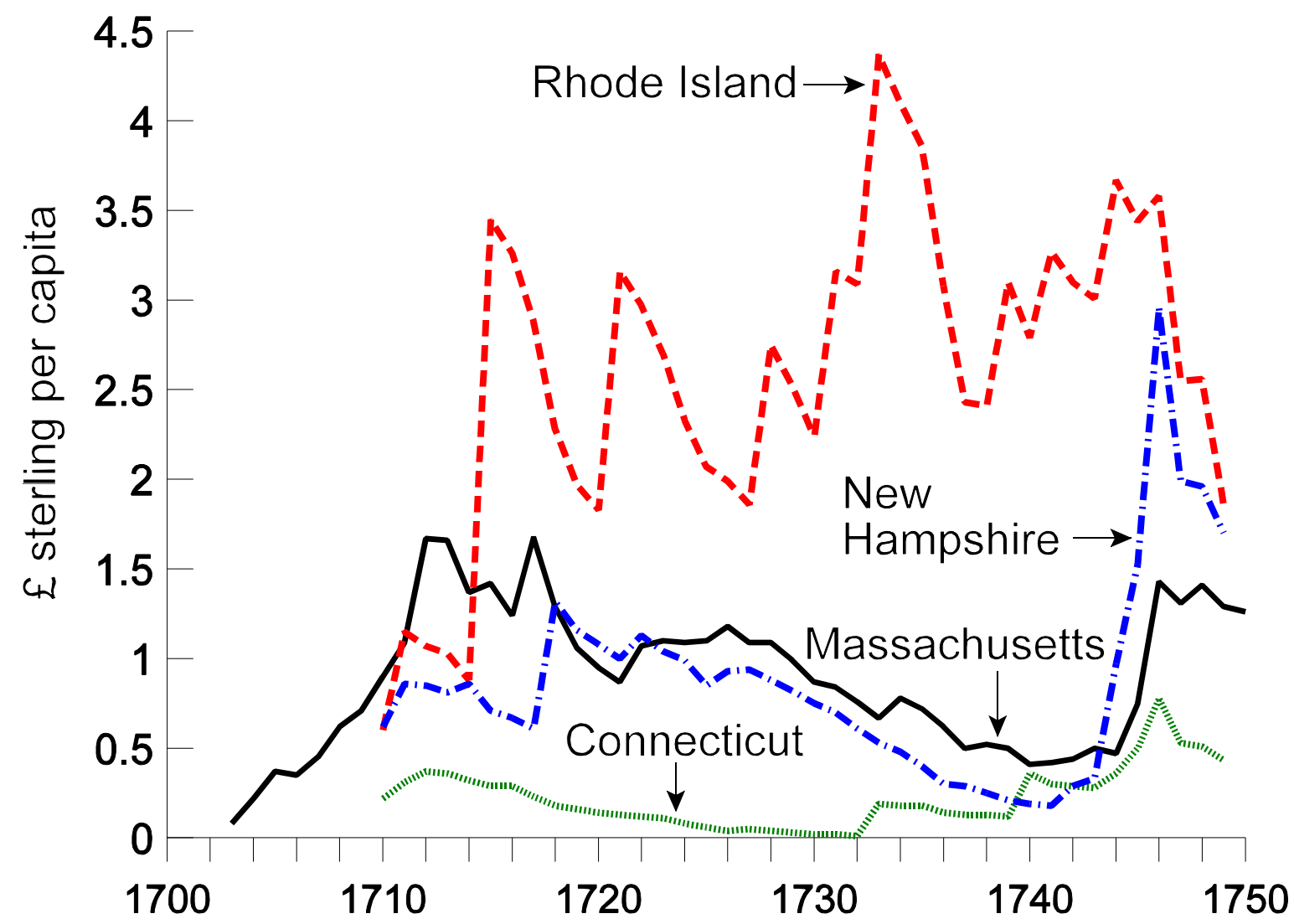

Figure 2. Bills of Credit Outstanding per Capita in the New England Colonies, 1703-1749.

money at the time and the amount of specie likely to have been in circulation, that much of the economy's transactions had to have occurred outside of the formal monetary system.

Figure 2 shows that the New England colonies were also unable to monetize adequately. ${ }^{4}$ These series were constructed using the same methodology as for the mid-Atlantic colonies in Figure 1 except that the sterling exchange rate for Massachusetts was also applied to the paper money stocks of Connecticut, New Hampshire, and Rhode Island. This is reasonable because the bills emitted by the New England colonies before 1750 were generally accepted across colonial

${ }^{4}$ Bills of credit in circulation for the New England colonies are from Brock (1992, table 1). Populations are from Bureau of the Census (1975, p. 1168, series Z-3, Z-6, Z-7, Z-11) and use constant growth rates to interpolate between decadal benchmarks. Sterling exchange rates are annual averages of local currency per $100 £$ sterling from McCusker (1978, table 3.1, pp. 138-45). 
borders at par with the home colony's own currency.

A few observations can be made at this point. First, the per capita stock of paper money declined in Massachusetts, New Hampshire and Connecticut through the 1720s and 1730s. By 1740 it had fallen to less than $£ 0.5$ in all three. Second, the behavior of Rhode Island's currency stock was much different, following an upward trend from 1710 through 1747 . This small state, with a population of 25,000, one-sixth that of Massachusetts, had discovered that it could issue paper money that would depreciate only to the extent that it undermined confidence in the money stock of the entire region, which in effect allowed Rhode Island to levy taxes indirectly on its neighbors. When the New England colonies all began to emit larger quantities after 1745 to pay for King George's War, the ensuing expansion of the region's money supply led to a runaway inflation. Recognizing its failure with paper money, Massachusetts reformed its currency between 1749 and 1754, at first using specie shipments from England that were belated compensation for expenditures made during King George's War to repurchase bills of credit. After the bills were collected and burned, Massachusetts issued only "treasurer's certificates," which bore interest and were redeemable on demand in silver. This effectively placed Massachusetts on a specie standard for the remainder of the colonial period. Connecticut and New Hampshire, though slower than Massachusetts in getting started, also enacted currency reforms to extinguish their bills of credit. Rhode Island's resistence to currency reform, on the other hand, hastened the Currency Act of 1751, a directive from the crown that forbade further issues of legal tender bills in the New England colonies, but currency reform commenced even here by 1763 .

Rhode Island's ability to exploit the system of currency finance for its own gain underscores an important disadvantage of monetary independence within a tightly-wound regional economy the domestic value of one currency becomes dependent on actions taken by other members of the 
"union." The forbidding of state note issues, formation of a central bank, and growth of the banking system early in the Federal period can be viewed as an attempt to reduce the possibility of these problems arising. And though banks were known to have over-issued notes over the nation's first half-century as well, and especially during the 1830 s, most of the time there was a central bank that could impose some discipline on note issues by collecting them and then presenting them at the issuing bank for redemption in specie. Excessive note issues by soon-to-be-insolvent banks in one region could disrupt the economy generally if they undermined confidence in other banks, but overissues by one bank, unlike that of a single colony, would be unlikely to disrupt the entire system.

Of all the colonies, South Carolina had the most tumultuous experiences with paper money. Figure 3 shows her bills of credit per capita along with those of North Carolina, again in sterling equivalents. ${ }^{5}$ Each of the three times that South Carolina issued bills in large quantities, rapid declines in the per capita stock of bills followed due to depreciation or the cessation of land combat. It is likely that conflicts with neighboring Indian tribes and Spain, both potential and actual, justified the first two waves of emissions, but the ability to extract seigniorage successfully through currency issues does not necessarily represent an effective monetary policy. Rather, the currency expansions were needed to compensate for the inability to raise revenues by other means. The situation in North Carolina was less fantastic but followed a similar rhythm.

\footnotetext{
${ }^{5}$ I constructed the sterling value of outstanding bills for North and South Carolina from records of issues and likely redemptions in Brock (1941, pp. 108-29). Populations are from Bureau of the Census (1975, p. 1168, series Z-15, Z-16) and include slaves, with constant growth rates to interpolate between decadal benchmarks. Sterling exchange rates are annual averages of local currency per $100 £$ sterling from McCusker (1978: table 3.11, pp. 217-9; and table 3.12, pp. 222-6). Linear interpolations between missing exchange rates were used if they facilitated additional observations for the sterling equivalent currency stock. Dashed lines connect endpoints of gaps in data. The plotted series for South Carolina does not include observations of $£ 3.14$ in 1712 , £2.78 in $1713, £ 1.84$ in 1714 , and $£ 1.71$ in 1716 .
} 


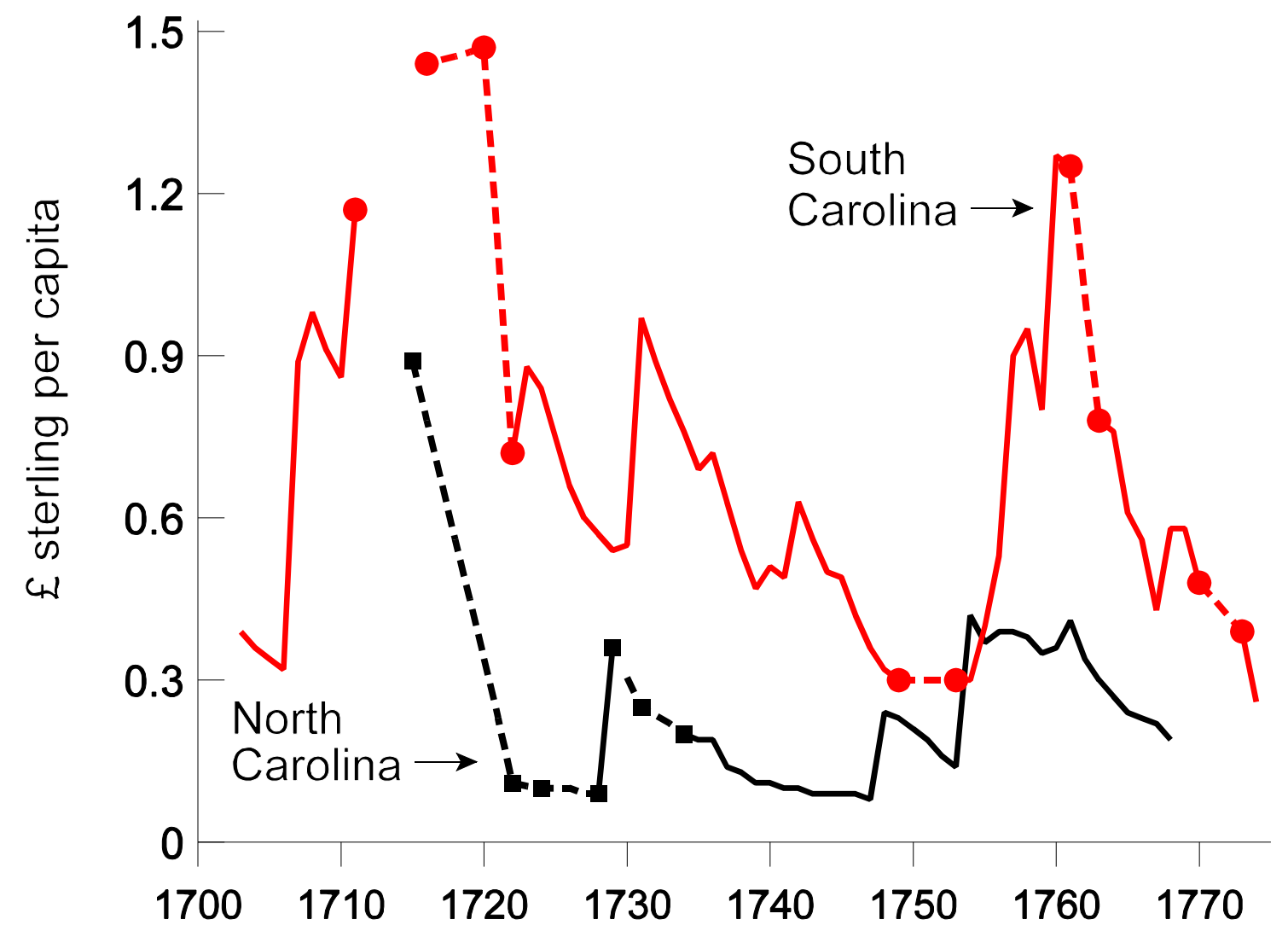

Figure 3. Bills of Credit Outstanding per Capita in the Carolinas, 1703-1774.

\subsection{Inelasticity of the Money Supply}

The available data suggests that the colonies had great difficulties in monetizing, but a nonincreasing stock of real money might still promote growth of a modern (i.e., market-oriented) sector if it expanded just enough in nominal terms to absorb the volume of transactions in that sector. One such modern-sector activity was international commerce. Large trade deficits affected the stock of specie because sterling bills of exchange would become scarce and specie would have to go abroad in settlements. With an elastic supply of paper money, fresh paper issues could replace the remitted specie until more could be obtained in the course of trade with South America and the West Indies or through military reimbursements from England. 


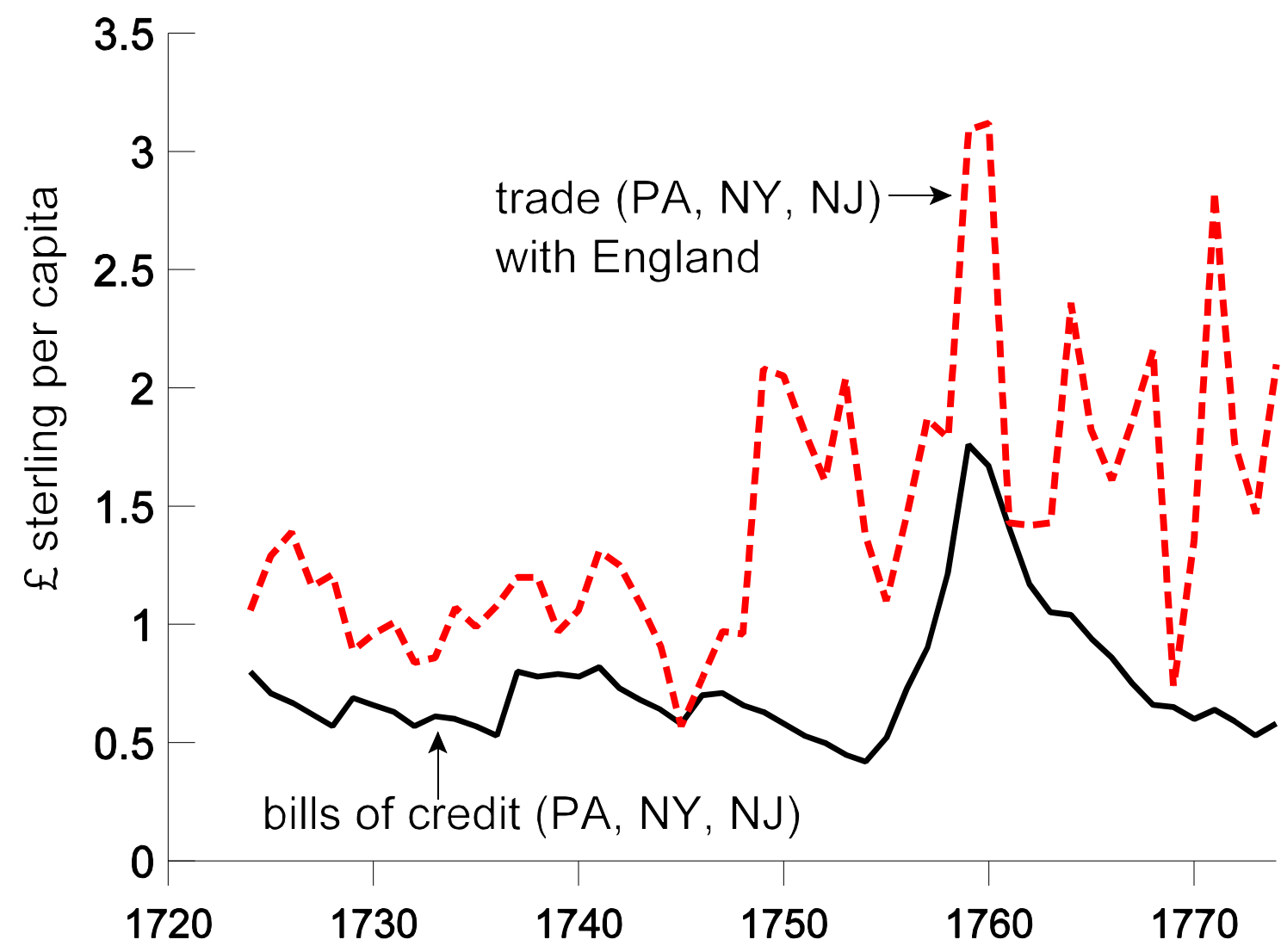

Figure 4. Bills of Credit Outstanding and Trade with England, Mid-Atlantic Colonies, 1723-1775.

The colonies, however, were unable to control the supply of paper money with any precision because the equivalent of today's "open market purchases" involved collecting taxes for which bills of credit were an accepted and desirable medium of payment and then burning the bills. Unfortunately, the bills were rarely redeemed according to schedule. The ability to expand the nominal money stock readily, especially to meet the needs of war, combined with an inability to contract it quickly imparted an inflationary bias to colonial monetary policy. When public confidence in the resolve to extinguish the bills in a timely manner fell, this bias would make the value of paper money difficult to sustain.

This is not to say that the money supply in some colonies showed no signs of elasticity. Figure 4, for example, shows some co-movement between per capita bills of credit and per capita 


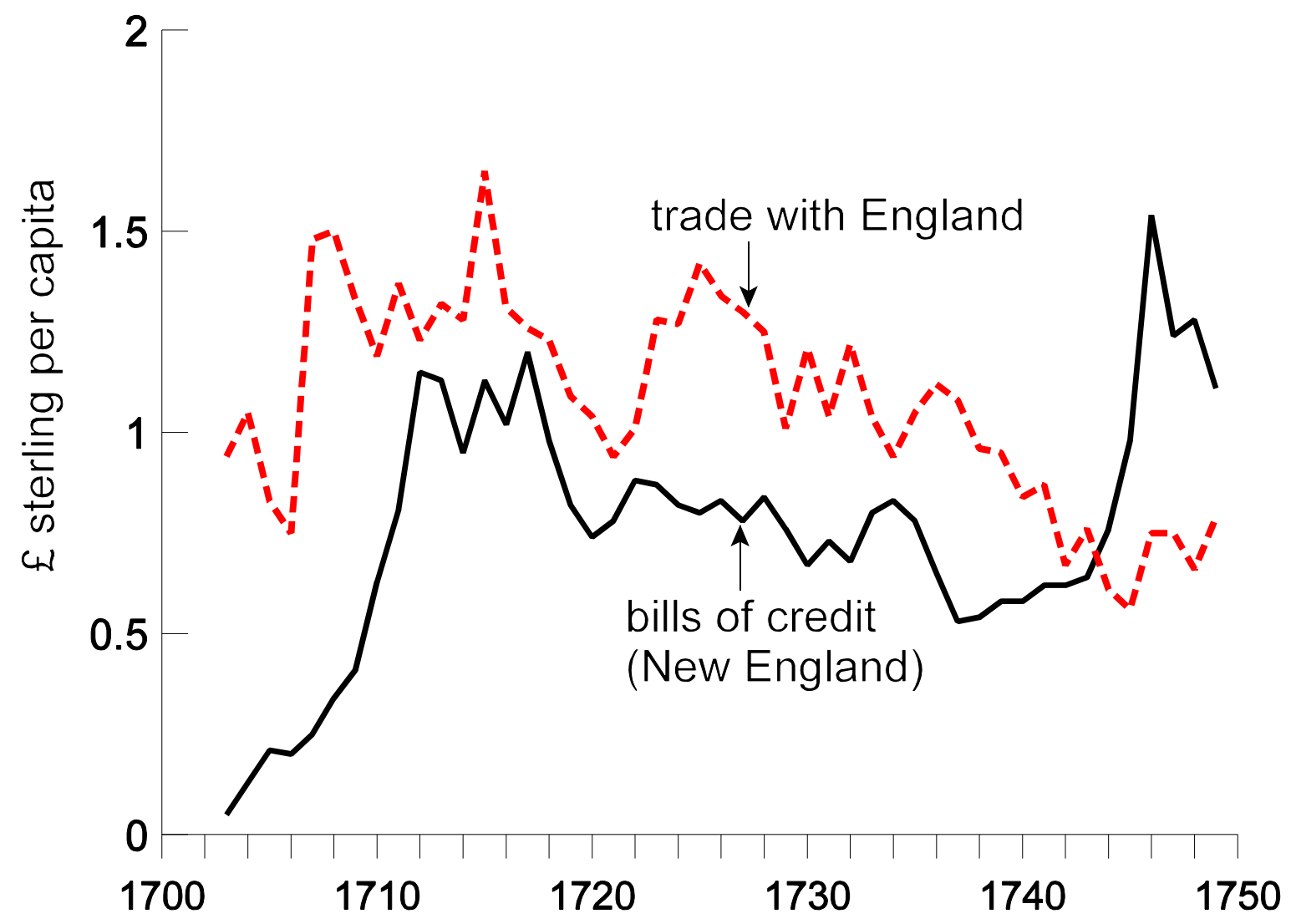

Figure 5. Bills of Credit Outstanding and Trade with England, New England, 1703-1749.

trade (the sum of exports and imports) with England for Pennsylvania, New York, and New Jersey combined. The coefficient of correlation between the series is $0.50 .{ }^{6}$ Of course, the correlation of the overall trade deficit and the stock of paper money would be a more useful measure of elasticity, but we just do not know the net payments position of the individual colonies with respect to their trading partners other than England. It is reasonable to operate under the working assumption, however, that larger trading volumes for the mid-Atlantic and New England colonies were correlated with larger deficits. I say this because the mid-Atlantic and New England colonies ran a

${ }^{6}$ The value of exports to and imports from England by New York and Pennsylvania are from Bureau of the Census (1975, series Z217-Z220, p. 1176). The foreign commerce of New Jersey was carried on through the New York and Philadelphia (Brock, 1992, p. 13). 


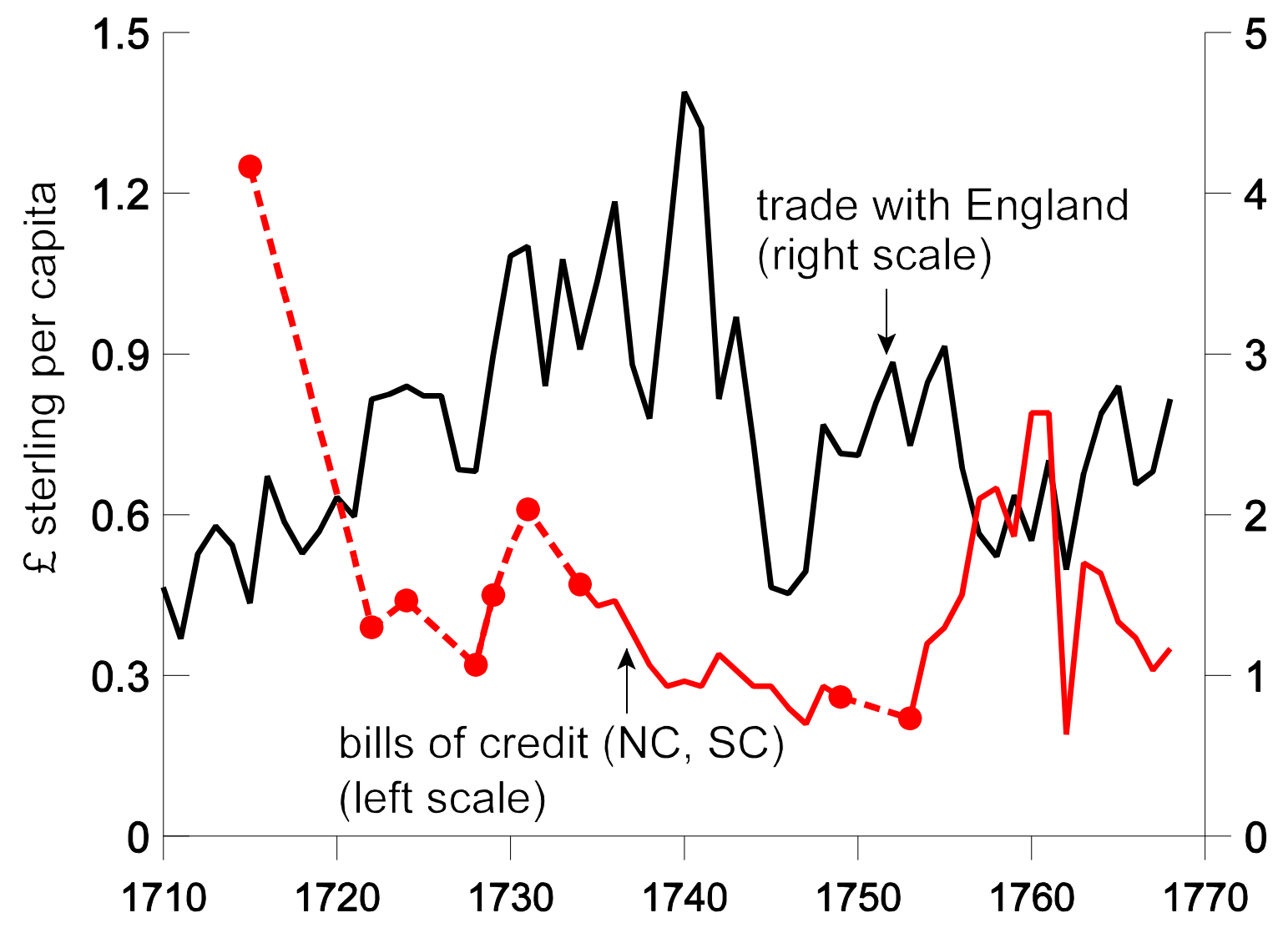

Figure 6. Bills of Credit Outstanding and English Trade in the Carolinas, 1710-1768.

substantial deficit with England in every year for which we have data, and the inflow of specie from Latin America was unpredictable. ${ }^{7}$ All of this suggests that the supply of paper money in the midAtlantic colonies was "responsive" to fluctuations in the flow of trade.

Figure 5, on the other hand, by this metric suggests that the New England colonies, with a correlation between the monetary and trade series of less than 0.01 , did not have an elastic currency. Figure 6 shows that the money stock of the Carolinas could also be characterized as inelastic (correlation coefficient of -0.17 for $1734-68$ ), though it is important to note that the evidence is

${ }^{7}$ See Figures 7, 8, and 9 below for a comparison of exports and imports for the mid-Atlantic colonies, the New England colonies, and the Carolinas respectively. 
weaker because these colonies did run trade surpluses with England in the 1720s and 1730s. ${ }^{8}$

Overall, the inelasticity of the colonial money supply was unlikely to have created conditions that were favorable for economic development.

In fairness, however, problems with an "inelastic" currency persisted well beyond the colonial period, and solving them was among the stated objectives of the Federal Reserve Act. Even then, failure to expand the money supply adequately when remains a leading candidate explanation for the impulse that started the Great Depression. But the inelasticity in the New England colonies and the Carolinas was unfortunate since an ability to manipulate the money supply on both margins could have provided greater price stability when catastrophic depreciations were not uncommon and the money stock would often swing rapidly due to events such as widening trade deficits, large repayments of war expenses in specie from England, or more favorable trade balances with the Latin America and the West Indies. Expansion of the nominal money supply was rarely difficult in the colonial period, but supporting its value through commitments to rein it back in without extraordinary measures proved to be nearly impossible.

\subsection{Financial Deepening (or Lack Thereof)}

Inelasticity of the money supply was an inconvenience for the American colonists, but it was probably not the greatest problem of the monetary system. Rather, it was inadequate growth in the real money supply that kept barter active and suppressed the emergence of a modern sector, even in those colonies where paper money systems operated adequately. The inability to modernize, of course, may have had as much or more to do with the extractive orientation of England's economic policies than with deficiencies in monetary arrangements. Nonetheless, the ability of

\footnotetext{
${ }^{8}$ See Figure 9 below for a comparison of exports and imports for the Carolinas. The value of exports to and imports from England by North Carolina and South Carolina combined are from Bureau of the Census (1975, series Z223-Z224, pp. 1176-7).
} 
colonies to use paper money to cope with restrictions imposed by the crown would have, in retrospect, been at best a weak endorsement of it for use in the period following the adoption of the Federal constitution.

Studies of financial development and growth in the macroeconomics literature (i.e., King and Levine 1993; Rousseau and Wachtel 1998) have identified ratios such as that of broad money to gross domestic product as useful in measuring the extent to which an economy has monetized, and also as a measure of the degree of its financial sophistication. Unfortunately, there is not enough data available to investigate this type of relationship econometrically in the colonial period. Even if a measure of colonial output were available, it would include the subsistence sector of a largely agricultural economy that operated for the most part outside of the formal market. Thus, a narrower measure of modern sector activity, such as trade or commerce, might be more useful as a normalization for the volume of money. In this section I use the ratio of bills of credit to trade with England to gain insights about the long-run evolution of financial depth.

Figure 7 shows this ratio for Pennsylvania, New York, and New Jersey combined from 1724 to 1774 . The series exhibits wide fluctuations throughout, but a downward trend is clear. The commercial sector grew, but financial deepening, in the absence of banks and securities markets, did not materialize.

The ratio for the New England colonies, shown in Figure 8, did not progress from 1710 to 1745 , but then rose rapidly when a flood of paper money was issued in the midst of King George's War (1745-48). Had these issues retained their value, some benefits of monetization might have been felt in the modern sector, but public confidence in the new bills deteriorated quickly. When provisions for their retirement were made in 1749 , the depreciation slowed as the bills were taken out of circulation and the region's experiment with legal-tender paper money came to an end. 


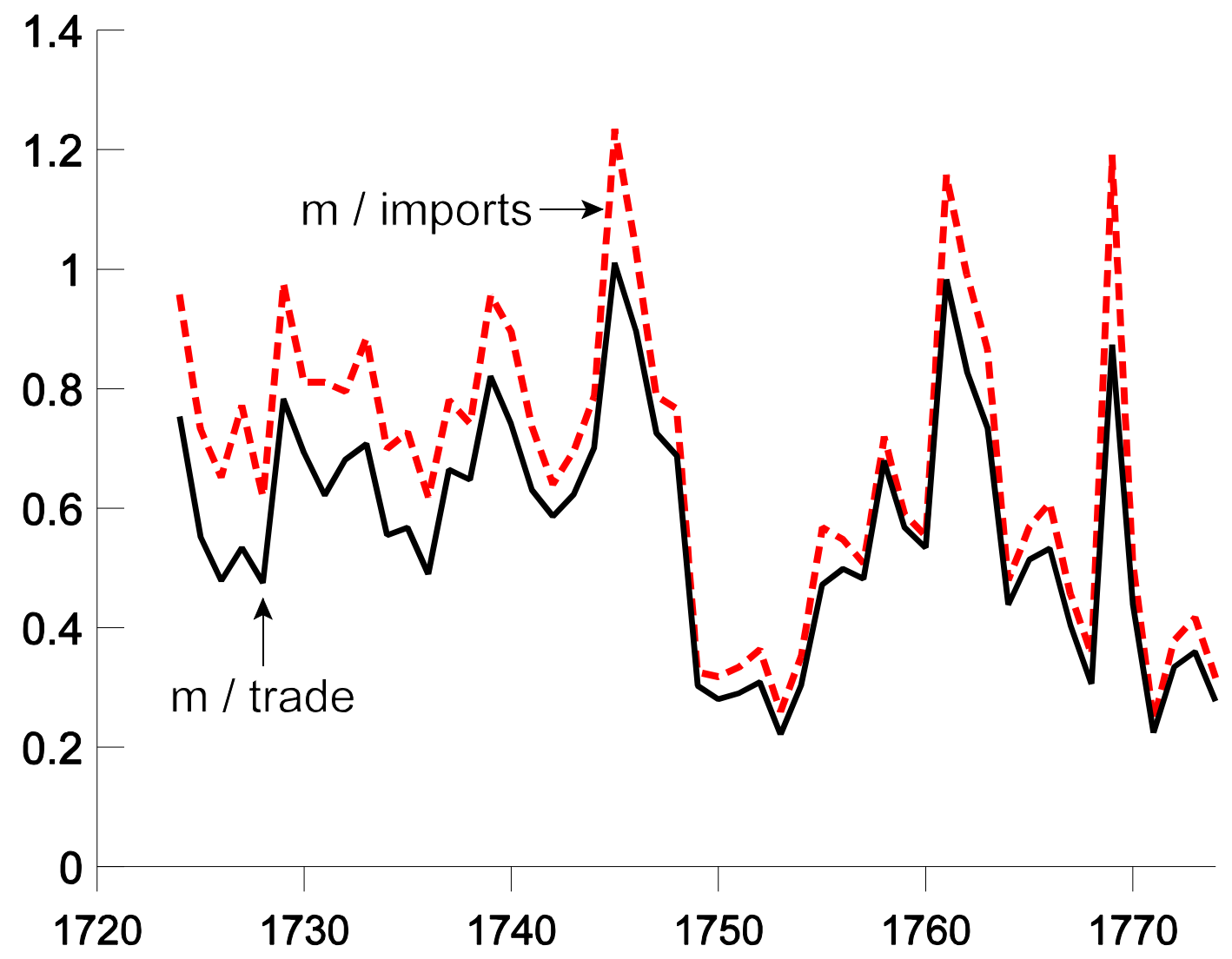

Figure 7. The Ratio of Bills of Credit in the Mid-Atlantic Colonies to Trade with England, 1710-74.

The conditions for North Carolina and South Carolina differed from those in the mid-

Atlantic and New England colonies in that exports made up a larger portion of the total trade with England for the Carolinas. At the same time, the ratio of bills of credit to trade fell from 1720 until the start of the Seven Years War. At that time fresh currency issues raised the measures of financial depth temporarily, but they quickly fell again to their pre-war levels by 1763 . The Carolinas, then, were yet another region where finance did not deepen over the course of the 18th century.

\subsection{Remarks on the Colonial Period}

In this section, I have offered some evidence to contradict the view, recently revived in Grubb (2003), that monetary conditions in the colonial period were conducive to long-run growth. 


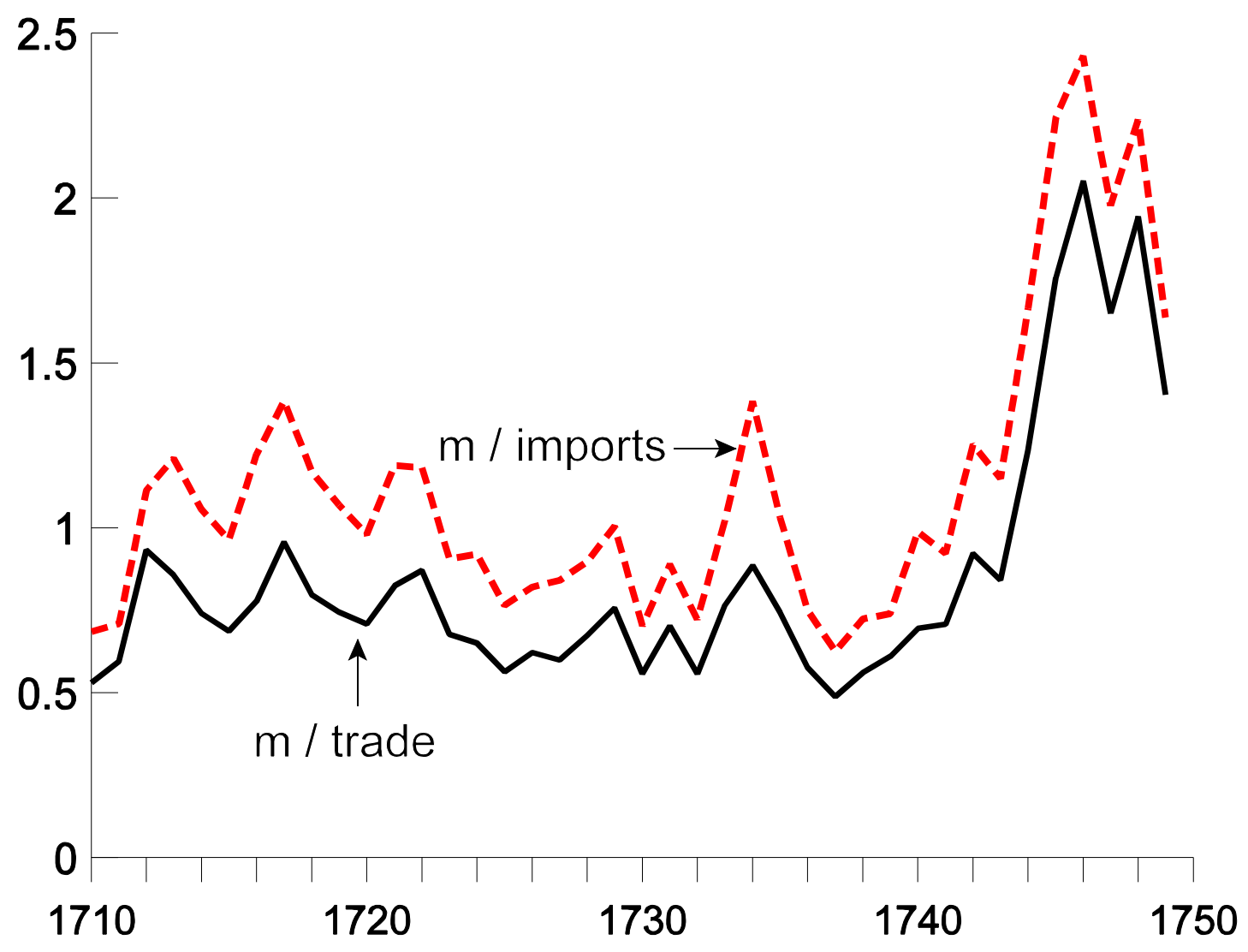

Figure 8. Ratio of Bills of Credit in New England to Trade with England, 1710-49.

Rather, currency finance seems to have been a reasonable response to restrictions imposed by England but was hardly a desirable long-run monetary arrangement. Indeed, the colonial period from a monetary standpoint can best be viewed as one of weak performance and frequent regression. Attempts to expand the money supply to meet transaction demands and the needs of commerce in the course of making advances on land and paying for military operations may have been well meant, but the lack of a credible policy for redeeming currency issues at well-defined points in the future led them to lose value, sometimes catastrophically. In all of the colonies examined here, including the mid-Atlantic successes, the money stock can be seen as inelastic and insufficient to support formation and growth of a modern economy. 


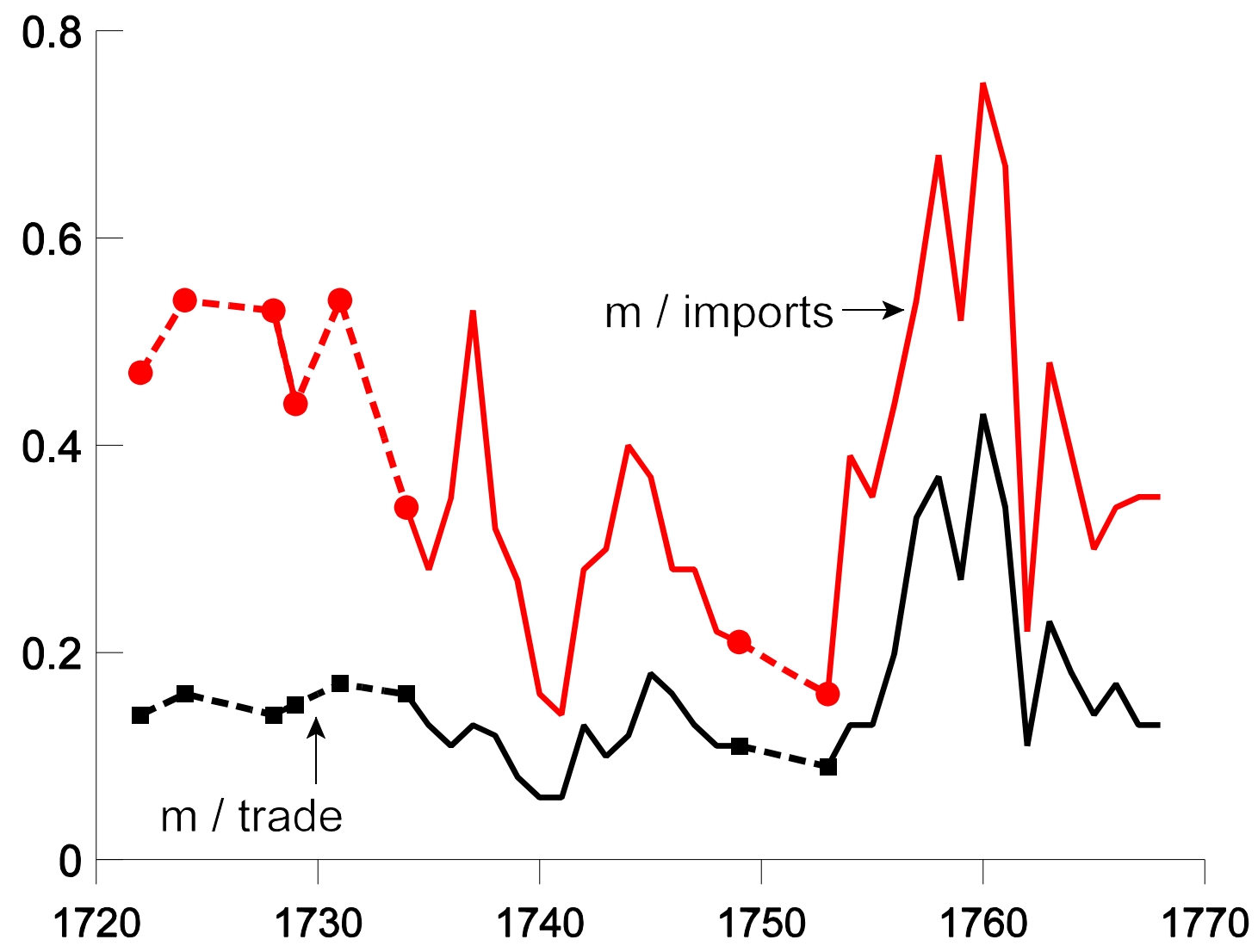

Figure 9. Ratio of Bills of Credit in the Carolinas to Trade with England, 1710-49.

In an earlier paper, Richard Sylla and I describe five components of a "good" financial system as 1) sound public finances and public debt management; 2) stable monetary arrangements; 3) a variety of banks, some with domestic and some with international orientations; 4) a central bank to stabilize domestic finances and manage international relations; and 5) well-functioning securities markets. ${ }^{9}$ And though these criteria by no means represent the final word on what a "good" financial system might include, it is worthwhile to observe that the American colonies did not develop any of these components.

\footnotetext{
${ }^{9}$ See Rousseau and Sylla (2003, p. 374-5).
} 
To be more specific, currency issue was the principal vehicle for public finance, and managing redemptions proved to be difficult at times and impossible at others. This led to monetary arrangements that were highly unstable, as evidenced by the evolution of the money stock in New England and the Carolinas. The only "banks" in existence at the time were land offices that allocated the public credit towards largely agricultural pursuits with little consideration of building a modern sector. There was no central bank, but rather a group of politician-statesmen who managed the money supply with little apparent concern for the effects that their actions might have outside of their respective colonies. Finally, securities markets, to the extent that they existed in New England and elsewhere, were at best thin and local in character (see Rothenberg 1985). Modern securities markets were a mere vision in the minds of the men who would soon begin the process of transforming the United States over the next century into the world's leading economy.

\section{The Early National Period}

\subsection{Revolution and Confederation}

The period of the Revolutionary War and the provisional government under the Articles of Confederation, though ending in military and political triumph for the former colonies, saw further deterioration of monetary control. Calomiris (1988), Perkins (1994), and Michener and Wright (2003), among others, describe how the Continental Congress, a political body that lacked the power to ensure redemption by levying taxes, authorized the issue of fiat currency to finance the conflict. Given the history of problems that the colonies had faced in redeeming their bills of credit, even with the authority to impose taxes, it is in retrospect not at all surprising that the new paper quickly depreciated virtually to the point of worthlessness.

The saga of the "continental" currency is a classic example of time inconsistency in monetary policy. The burden of financing the war, which was much greater than experienced in the 
Seven Years War, and with no possibility of repayments from England, called for drastic measures.

The former colonists had never experimented with a common currency, and when debt proved difficult to raise domestically, fiat money became a viable option for financing the War of Independence. Uncertainty about the size of the new issues and perhaps even misplaced optimism about the terms of their redemption allowed the bills to retain their value long enough to support expenditures in the first few years. When the paper depreciated, however, the Federal legislature could not successfully turn to the device a second time. The continental was officially devalued at 40:1 in 1781, which helped to encourage its use in tax payments, and in the end Hamilton's funding plan of the 1790s provided for redemption of the remaining bills at a ratio of 100:1 (Perkins, 1994, pp. 97-98).

The thirteen states also issued their own fiat currencies during the War of Independence, and rapid depreciation commenced on these as well. By the mid-1780s, seven states had reissued fiat currencies that were backed by future tax collections, but these never managed to circulate at par. Pennsylvania, for example, which is often credited with having among the more stable of these later monetary arrangements, saw its currency value depreciate by 20 percent against sterling between November 1780 and June 1785 (Bezanson, 1951, p. 346). At the same time, the Federal government was in default on its foreign debts, primarily to the French government and to Dutch investors. The 1780s saw attempts by financial leaders such as Robert Morris and Alexander Hamilton to hasten the privatization of the financial system by establishing the nation's first real banks in the commercial centers of Philadelphia and New York (see Perkins, 1994, especially chapter 6). Political opposition to these banks was strong, however, and they were at that time unable to serve as much more than a model for the changes that were to come.

In other words, the ability of the young United States to finance its military efforts in the 
War of Independence does not imply that its earliest monetary policies were optimal or stable. After all, an ability to write-down (and effectively write-off) state and federal obligations at pennies on the dollar can hardly be considered a desirable policy - even among a general population that was reluctantly willing to accept the issues as the taxes that they were. Further, the depreciating currency, in the absence of a banking system or organized and liquid securities markets, was forced to perform the function of a store of value for many of the colonists. It is clear why savings and capital accumulation were stunted under such conditions. In all, currency managed to function as a medium of exchange during the war and confederation periods, but failed as a store of value, and as a unit of account suffered from instability and confusion associated with a multiplicity of issues.

\subsection{The "Federalist Financial Revolution"}

By any standards, the U.S. economy experienced a near-miraculous turnaround in the last decade of the 18th century, when it made the transition from a defaulting debtor awash in obligations left over from the war to a magnet for international capital flows. Any skeptic of the importance of monetization and finance in promoting economic growth must come to grips with the sweeping change that followed the adoption of the Federal Constitution in 1789. At no other point in history did the five elements of a "good" financial system develop so rapidly. Much of the credit for what Richard Sylla (1998) has termed the "Federalist financial revolution" seems appropriate to bestow upon the nation's first Secretary of the Treasury, Alexander Hamilton. Hamilton's reforms affected the real side of the economy quickly, but were perhaps not fully felt for another quarter century when the "modern" sector emerged.

The chartering of a national bank, the First Bank of the United States, and Hamilton's idea of allowing Federal debt securities to be tendered for shares therein by 1791 had raised to par and above the re-structured U.S. debt, which included assumed state debts as well as federal domestic 
and foreign debts. Securities markets in New York, Philadelphia and Boston quickly sprang up to trade these securities and others associated with internal improvements. Hamilton also established a federal mint, bringing order to the collection of foreign coins and various issues of paper currency that had previously comprised the nation's money stock under a bi-metallic standard, and formally introduced the dollar as the common unit of account. The banking system would grow rapidly over the next fifty years, with the number of banks rising from a mere 3 in 1791 to more than 800 by 1840, and the paid-in capital of the banking system would increase more than 100 times over.

It was not so much growth in the amount of currency available for transactions that promoted the modernization of the U.S. economy, however, as it was the way in which it grew, in particular by increasing opportunities for private sector credit through the banking system. Rather than having a system in which government officials and politicians controlled the money supply process and the direction of credit - largely to the agricultural sector - banks were able to amass private capital and issue notes that could promote investment and foreign trade. This shift in emphasis to the private sector credit helped to poise the nation for industrialization by 1815 , a feat that would have been more difficult had the money supply remained under the control of state legislatures.

The innovativeness of the early U.S. financial system and the scope of Hamilton's role is documented in Sylla (1998) and Rousseau and Sylla $(1999,2004)$. In the next section I will focus on comparing this system quantitatively with the colonial arrangements that existed prior to the War of Independence.

\subsection{Monetization}

The starting point for my comparison of the colonial and early Federal periods is an examination of the per capita money stock. And though it is difficult to measure the quantity of 


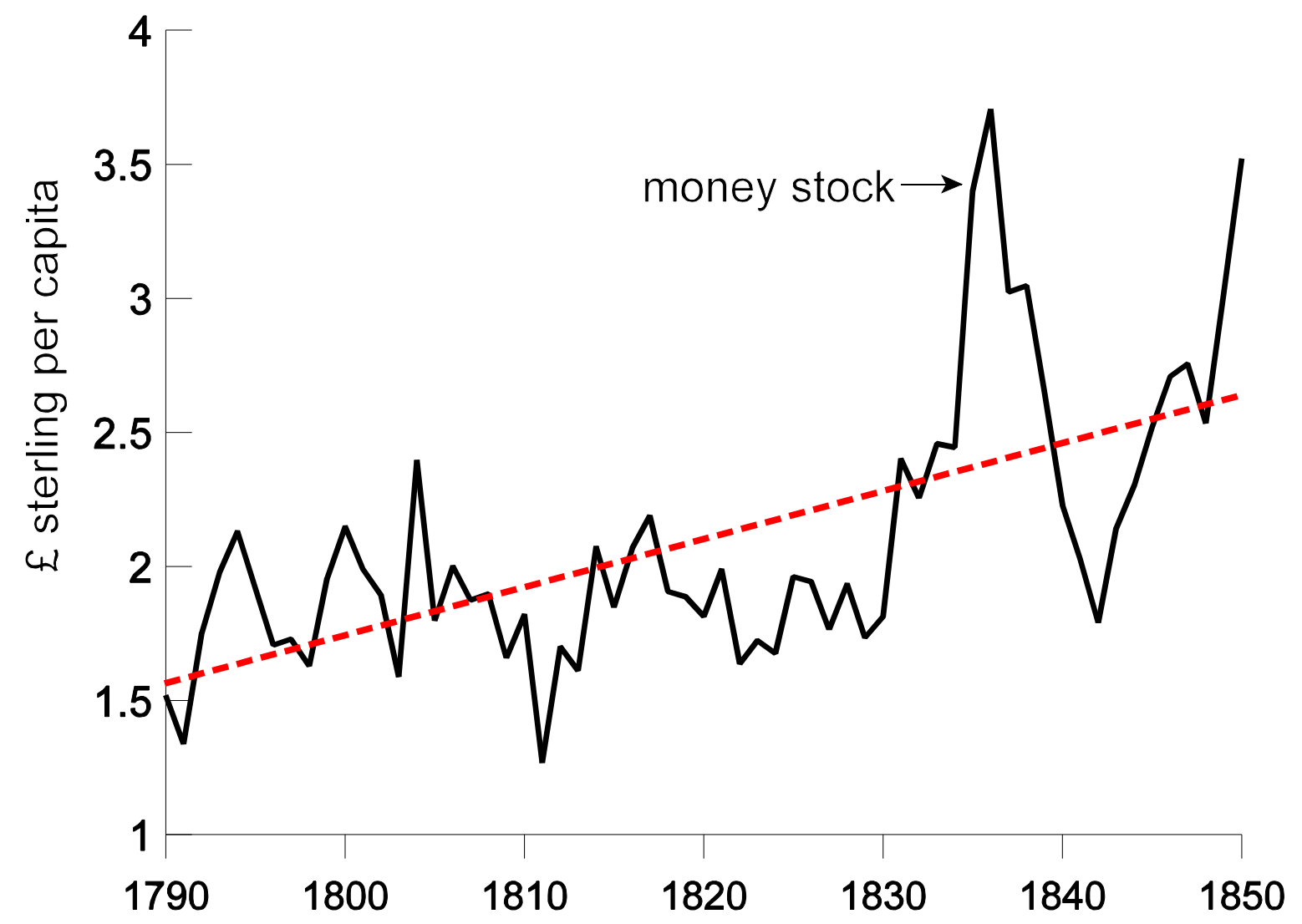

Figure 10. The Per Capita Stock of Money in Sterling Equivalents, 1790-1850.

specie in the hands of the public with confidence, Rousseau and Sylla $(1999,2004)$ use the available data to extend Temin's (1969) series, which begins in 1820, back to 1790 by replicating Temin's method as closely as possible. ${ }^{10}$ The resulting series includes obligations of banks to the public and specie outside of banks, and thus represent assets that are either acceptable or quickly convertible for use in market transactions. Increases in the real value of these assets reflect more widespread use of the market economy, and might be plausibly linked to modern sector activity such as trade and investment.

Figure 10 presents the money stock for 1790-1850 using Temin's estimates for the post-

${ }^{10}$ The data and methods used to construct the annual series for the U.S. money stock are described in detail in Appendix A of Rousseau and Sylla (1999, pp. 48-50). 
1920 period and expressing the stock in per capita sterling equivalents using the official exchange rate of $\$ 4.87$ per pound sterling. The conversion allows comparisons with the levels achieved by the various colonies prior to Independence. The trend line, which are the fitted values of a regression of the money stock on a linear time trend, is positively sloped and reflects an average growth rate of 0.8 percent per year. The period of most rapid expansion occurred in the first 15 years after Hamilton's plans were enacted, when trend growth reached 1.7 percent per annum, and again after 1830. With the exception of one year the per capita money stock always exceeded its 1790 level. The mean of the series is $£ 2.1$, or about $\$ 10.23$ per person.

In the colonial period, bills of credit per capita for the mid-Atlantic colonies averaged $£ 0.65$ (\$3.17) for Pennsylvania (1723-74), £ 0.88 (\$ 4.29) for New York (1709-74), and $£ 0.70$ (\$3.41) for New Jersey (Figure 1). For the mid-Atlantic colonies as a whole, trend growth in bills per capita was only 0.6 percent per annum from 1724-74 (Figure 4). For New England, the mean level of bills per capita for $1710-49$ was $£ 0.85$ (\$ 4.14) and the trend growth rate was slightly negative (Figures 2 and 5). The Carolinas (1722-68) had a mean holding of $£ 0.41$ (\$2.00) per capita and experienced quite negative trend growth (Figures 3 and 6). ${ }^{11}$ All of the colonial levels were well below those achieved in the early Federal period, even after taking into account a total increase in the English price level of 20 percent between 1730 and 1850 and a generous guess of 40 percent for the share of specie in the colonial money stock. It was only after 1790 that the U.S. economy truly began to monetize.

\subsection{Financial Deepening}

Using the same metric to capture modern sector activity as for the colonial period, Figure 11

\footnotetext{
${ }^{11}$ I computed the times series mean of bills of credit for the Carolinas using only actual observations rather than including the interpolated values in Figure 6.
} 


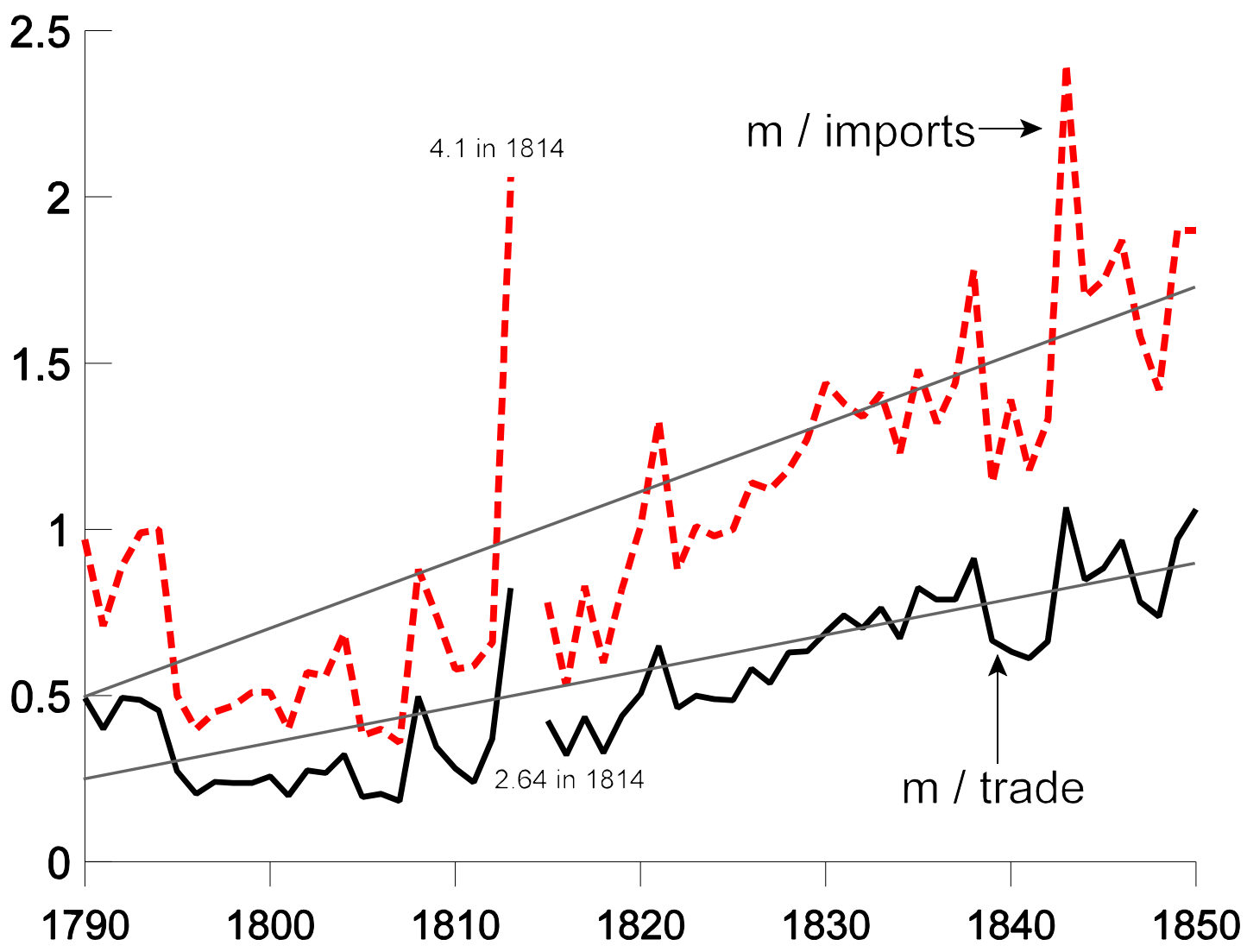

Figure 11. The Ratio of Money to Imports and Foreign Trade, 1790-1850.

shows the ratio of the money stock to the market value of imports and total foreign trade in the United States from 1790 to $1850 .{ }^{12}$ The regression lines that accompany the series indicate an upward trend for both, with identical trend growth rates of 2.1 percent per year. This stands in sharp contrast to the mid-Atlantic colonies, for which trend growth was -0.7 percent per year for the ratio of bills of credit to total trade from $1724-74$, and -1.0 percent for the ratio of bills of credit to imports. In the New England colonies from 1710-49, annual trend growth was 2.1 percent for the ratio of bills to trade and was 1.6 percent for the ratio of bills to imports. Since the ratios have a downward trend before 1740, the positive trend growth over the entire 1710-49 period can be

\footnotetext{
${ }^{12}$ Foreign trade is the sum of total exports and imports from Bureau of the Census (1975, series U1 and U8, pp. 865-866).
} 
wholly attributed to large currency issues in the midst of King George's War.

Overall, the U.S. economy made steady progress in monetizing as measured by the stock of money per capita, and these advances appear to have promoted its modernization in terms of financial depth.

\subsection{Linking Monetization, Finance, and Modern Sector Emergence}

Limitations of the available data on macroeconomic outcomes for the colonies render a systematic investigation of empirical links between the money stock and measures of the modern sector such as output, investment, and commerce not possible using modern econometrics. The main problems are incomplete figures on foreign trade and insufficient information to estimate the stock of specie from colony to colony. Fortunately, better data are available to measure development of the "modern" sector in the early Federal period, at least if we consider private domestic investment and foreign trade as broadly reflective of activity in that sector. This section reports the results of an investigation of links between monetization and growth from 1790 to 1850 .

Figure 12 shows foreign trade and private domestic investment in real 1840 U.S. dollars.

The series rise slowly in real terms until 1815 and then begin to accelerate, which is consistent with the rise of a modern sector at about this time.

On the financial side, Figure 13 shows the money stock, also in 1840 U.S. dollars, as well as the number of securities listings that appeared in the financial press of three major cities (New York, Philadelphia, and Boston) near the end of each calendar year. Rousseau and Sylla (1999, 2004) describe the construction of both series in detail. In the regression approach that I will take, including the number of securities in the empirical model controls for the size (and perhaps the sophistication) of the financial system that existed outside of banking, and may better isolate the independent impact of monetization on the real sector aggregates given that banks and securities 


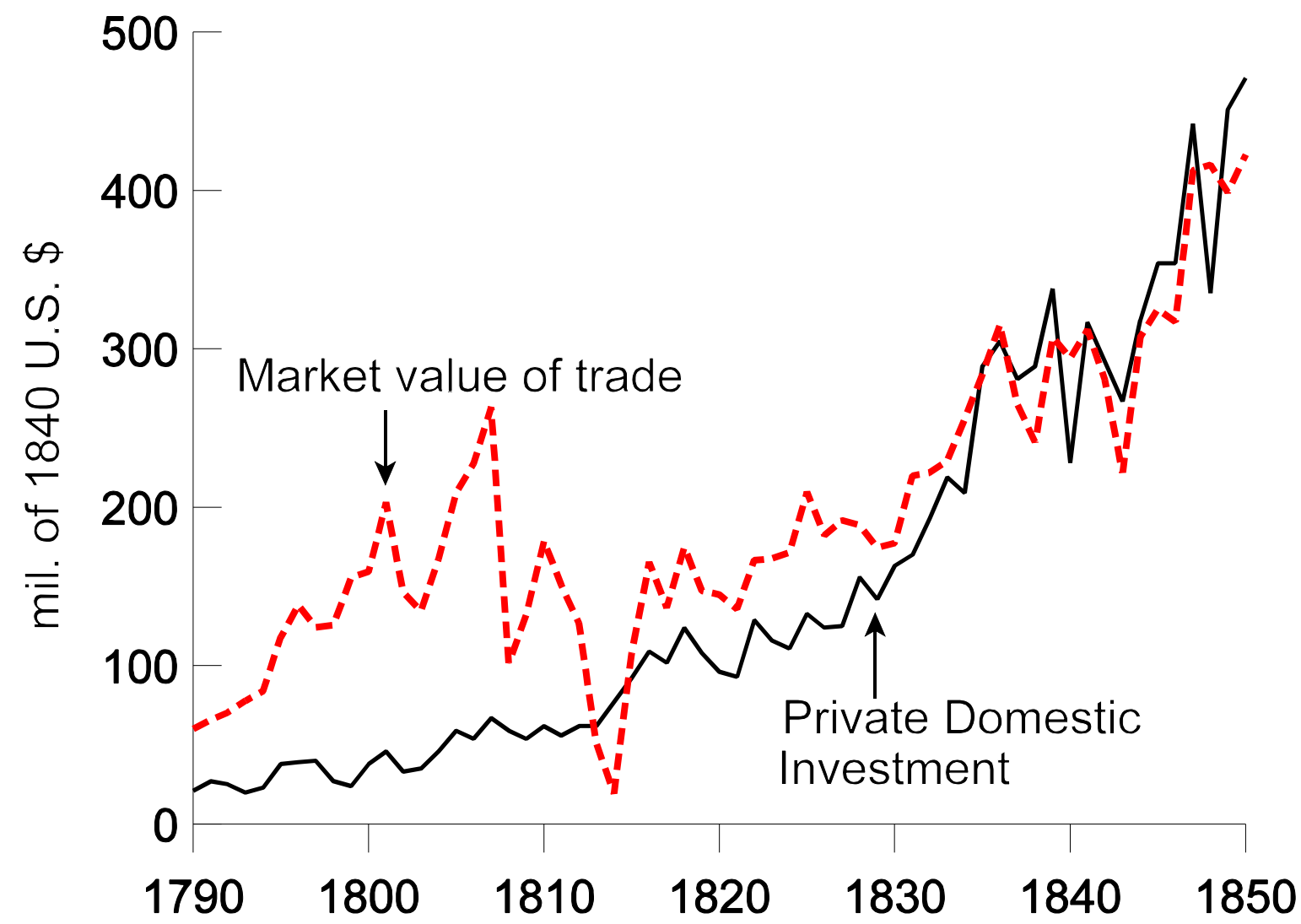

Figure 12. Investment and Foreign Trade in the United States, 1790-1850.

markets appear to be complementary inputs to the growth process (Levine and Zervos 1998;

Rousseau and Wachtel 2000). Both money and securities listings grow slowly until about 1815 and then began to rise quickly. Overall, both series grow at an average rate of about 4.5 percent per year, which is higher than the 1.9 percent growth rate of GDP (calculated from Berry 1988) and implies rapid financial deepening.

To explore links between the financial and real sector variables described above, I start with a vector autoregressive (VAR) specification that includes measures of investment, trade, and monetization. I will then add the number of listed securities to this system to measure their 


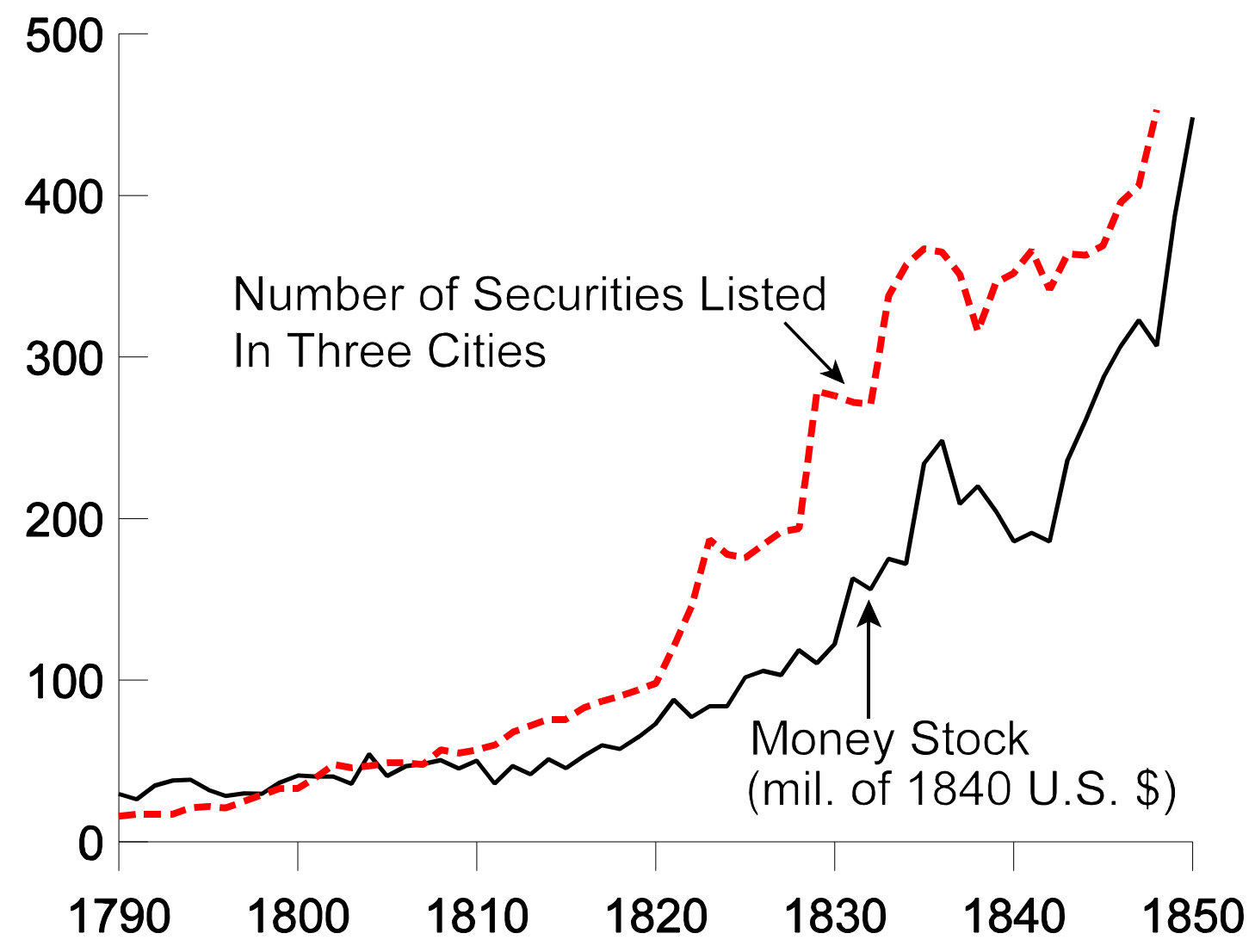

Figure 13. Monetary and Financial Aggregates, United States 1790-1850.

additional impact, and more importantly to observe the effects of their inclusion on the strength of links from the money stock to real activity.

The VAR approach facilitates investigation of dynamic interactions in stationary multivariate systems of time series without imposing a priori structural restrictions. To investigate the relationship between, say, real investment, foreign trade, and the money stock, a VAR would include a separate equation for each variable in the system and then regress each of the variables on its own lags and those of the other variables: 


$$
\begin{aligned}
& x_{1, t}=a_{1,0}+\sum_{i=1}^{k} a_{1, i} x_{1, t-i}+\sum_{i=1}^{k} b_{1, i} x_{2, t-i}+\sum_{i=1}^{k} c_{1, i} x_{3, t-i}+u_{1, t} \\
& x_{2, t}=a_{2,0}+\sum_{i=1}^{k} a_{2, i} x_{1, t-i}+\sum_{i=1}^{k} b_{2, i} x_{2, t-i}+\sum_{i=1}^{k} c_{2, i} x_{3, t-i}+u_{2, t} \\
& x_{3, t}=a_{3,0}+\sum_{i=1}^{k} a_{3, i} x_{1, t-i}+\sum_{i=1}^{k} b_{3, i} x_{2, t-i}+\sum_{i=1}^{k} c_{3, i} x_{3, t-i}+u_{3, t}
\end{aligned}
$$

where $x_{1}$ is the time series for investment, $x_{2}$ is foreign trade, $x_{3}$ is the money stock, and $k$ is the number of lags in the system.

Stationarity of a VAR is important in interpreting tests for Granger non-causality, that is, the hypothesis that past values of a variable do not jointly improve one-step ahead forecasts of another. Specifically, the null hypothesis implies the following joint restrictions on the coefficients in (1):

$$
\hat{l}_{j, i}=\hat{l}_{j, i+1}=\ldots=\hat{l}_{j, k}=0 \quad l=a, b, c ; j=1,2,3 .
$$

In general, the distributions of these tests are nonstandard when the VAR contains variables with unit roots (i.e., that are non-stationary), and differencing is usually required to ensure stationarity. Sims, Stock, and Watson (1990) show, however, that tests for Granger causality conform to standard distributions in tri-variate VARs with unit roots so long as a cointegrating relationship exists among the variables. I apply this result to the first system that I examine here because the null hypothesis of a unit root is not rejected with standard tests for any of the variables and there appears to be cointegrating relationship in each system. ${ }^{13}$ Running a VAR in levels is advantageous because it allows joint evaluation of short and long-term effects of movements in one variable upon others

${ }^{13}$ Augmented Dickey-Fuller tests show that the four series that I consider are indistinguishable statistically from unit root processes. Johansen (1991) tests (with a constant and trend in the test specification) indicate that the two systems that I estimate are cointegrated, which points to running the VARs in levels form. 
in the system.

Granger-causality tests must be interpreted cautiously because rejection of the block exclusion restrictions do not necessarily imply causality in an economic sense. This is because the validity of the test is predicated on the inclusion of the full information set in the VAR. Since this condition is violated in any finite regression framework, especially when the available data do not precisely reflect the desired theoretical constructs, the results presented below are only suggestive of the nature of linkages between finance, trade and investment in the early Federal period.

Table 1 presents the results from the VARs. Each cell includes the sum of the estimated coefficients for the variable listed in the respective column heading, with the p-value for the null hypothesis of Granger non-causality of that variable in parentheses. The equation numbers from the text are noted in the left-hand column. In the upper panel of Table 1, the null hypothesis that lags of the money stock do not Granger-cause real investment can be rejected at the 2 percent level (top line, third column) and the null hypothesis that money does not Granger-cause the value of real trade can be rejected at the one percent level (second line, second column). These results are consistent with the monetization of the U.S. economy having a positive effect on real activity in the modern sector. There is no evidence of any feedback from trade to the money stock (i.e., the null hypothesis of Granger non-causality cannot be rejected for lags of trade in equation (1c)), and investment Granger-causes money at the 8 percent level. Trade Granger-causes investment at the 10 percent level, but has a negative overall effect, which suggests that increases in the import component of trade may have to some degree "crowded out" investment.

In the lower panel, I add the number of listed securities to the VAR system to see if the effects of money on trade and investment are diminished by its inclusion. One might expect this to happen if money and securities markets development are collinear due to bias caused by omitting 
Table 1

VARs of financial and real activity, United States 1790-1850

\begin{tabular}{|c|c|c|c|c|c|}
\hline Eq. & Investment & $\begin{array}{c}\text { Market value } \\
\text { trade }\end{array}$ & Money stock & $\begin{array}{l}\text { No. listed } \\
\text { securities } \\
\end{array}$ & $\begin{array}{c}\text { Adjusted } \\
\mathrm{R}^{2} \\
\end{array}$ \\
\hline $1 \mathrm{a}$ & $\begin{array}{c}0.717 \\
(0.000)\end{array}$ & $\begin{array}{l}-0.266 \\
(0.094)\end{array}$ & $\begin{array}{c}0.423 \\
(0.018)\end{array}$ & & 0.964 \\
\hline $1 b$ & $\begin{array}{l}-0.239 \\
(0.799)\end{array}$ & $\begin{array}{c}0.377 \\
(0.001)\end{array}$ & $\begin{array}{c}0.549 \\
(0.010)\end{array}$ & & 0.663 \\
\hline $1 \mathrm{c}$ & $\begin{array}{c}0.154 \\
(0.075)\end{array}$ & $\begin{array}{c}0.037 \\
(0.958)\end{array}$ & $\begin{array}{c}0.840 \\
(0.000)\end{array}$ & & 0.973 \\
\hline Eq. & Investment & $\begin{array}{c}\text { Market value } \\
\text { trade }\end{array}$ & Money stock & $\begin{array}{l}\text { No. listed } \\
\text { securities }\end{array}$ & $\begin{array}{c}\text { Adjusted } \\
\mathrm{R}^{2}\end{array}$ \\
\hline $1 \mathrm{a}$ & $\begin{array}{c}0.245 \\
(0.570)\end{array}$ & $\begin{array}{l}-0.253 \\
(0.025)\end{array}$ & $\begin{array}{c}0.281 \\
(0.009)\end{array}$ & $\begin{array}{c}0.470 \\
(0.005)\end{array}$ & 0.972 \\
\hline $1 b$ & $\begin{array}{l}-0.050 \\
(0.918)\end{array}$ & $\begin{array}{c}0.373 \\
(0.001)\end{array}$ & $\begin{array}{c}0.597 \\
(0.004)\end{array}$ & $\begin{array}{l}-0.185 \\
(0.391)\end{array}$ & 0.664 \\
\hline $1 \mathrm{c}$ & $\begin{array}{c}0.089 \\
(0.168)\end{array}$ & $\begin{array}{c}0.032 \\
(0.961)\end{array}$ & $\begin{array}{c}0.823 \\
(0.000)\end{array}$ & $\begin{array}{c}0.074 \\
(0.669)\end{array}$ & 0.971 \\
\hline $1 \mathrm{~d}$ & $\begin{array}{l}-0.053 \\
(0.772)\end{array}$ & $\begin{array}{l}-0.013 \\
(0.879)\end{array}$ & $\begin{array}{l}-0.015 \\
(0.662)\end{array}$ & $\begin{array}{c}1.042 \\
(0.000)\end{array}$ & 0.991 \\
\hline
\end{tabular}

NOTE: Equation numbers correspond to those in the text. The VARs use four lags that were selected using nested likelihood ratio tests. The data are in real log levels. The table reports the sum of the regression coefficients for each variable block, with the significance level of the F-test for Granger non-causality in parentheses beneath the coefficient sums. The dependent variables for equations (1a), (1b), and (1c) are the respective column headings from left to right. The lower panel reports results from a four-dimensional system, which requires an extra equation (1d) in the VAR.

the number of securities from the system in the upper panel. Interestingly, the inclusion of the number of listed securities, though it Granger causes investment at the 1 percent level in its own right, only makes the effects of money on investment and trade stronger. It also eliminates any feedback at all from investment to money. Listed securities do not Granger-cause trade, however, which suggests that the rise of securities markets had their largest effects in the domestic capital 
market. I interpret this as reasonably strong evidence that monetization exerted an effect on the emergence of the modern sector independent of other developments in the early U.S. finance.

\section{Conclusion}

In this paper I organize existing data on bills of credit, exchange rates, and the extent of trade for the colonial period of U.S. history (1703-1774), estimate annual series of the currency stock for nine of the colonies in sterling equivalents, and compare their implications for monetization and economic modernization with those obtained for the early Federal period (17901850) by employing new estimates of the aggregate money stock. I find that colonial monetary arrangements worked reasonably well at times, even showing some elasticity with respect to foreign trade in the mid-Atlantic colonies, but were for the most part inadequate, leaving the colonies with a circulating medium that was often in short supply and could not serve as an effective store of value due to concerns about its depreciation. These conditions were not conducive to growth in international trade and commerce and in the modern sector more generally.

The changes of the early Federal period, which brought with it a central bank and a system of note-issuing banks were a considerable improvement over the arrangements that had existed previously. Privatization of banking and the process of credit allocation allowed the young United States to make more efficient use of the financial resources that were available to it. Descriptive statistics show that monetization proceeded at faster pace from 1790-1805, and indeed over the entire 1790-1850 period, than it did in the colonies prior to the War of Independence. Econometric evidence indicates a leading role for expansion of the money stock in the emergence of the modern sector over the 60 years following the adoption of the Federal constitution.

The backing of the U.S. money supply with a specie base rather than vague promises about its eventual retirement through tax collections created confidence in the nation's currency and 
ultimately in its creditworthiness. Fiat currency works in the United States today because the country got its financial house in order early on and over time achieved the five components of a good financial system that I have outlined above. Having a well-organized central bank that is committed to maintaining monetary control through the market for government bonds and the banking system is the key factor behind the success of today's fiat standard. Colonial legislators, subject to political pressures, could not make such commitments and thus could not devise an effective arrangement with fiat money. With the nation on the brink of bankruptcy, Hamilton's campaign to restore confidence in the U.S. financial system had a firmly-backed currency as its

core. It was a solution that was necessary at the time the Constitution was ratified and that remained necessary, though interrupted for a time by the Civil War and its aftermath, for nearly a century and a half. The U.S. economy would not have grown so rapidly in its early history without it.

\section{REFERENCES}

Berry, Thomas Senior, "Production and Population Since 1789: Revised GNP Series in Constant Dollars." Bostwick Paper No. 6. Richmond VA: The Bostwick Press, 1988.

Bezanson, Anne. Prices and Inflation During the American Revolution: Pennsylvania, 1770-1790. Philadelphia: University of Pennsylvania Press, 1951.

Brock, Leslie V. The Currency of the American Colonies, 1700-1764: A Study in Colonial Finance and Imperial Relations. Ph.D. Dissertation, University of Michigan, 1941. Reprinted New York: Arno Press, 1975.

Brock, Leslie V. "The Colonial Currency, Prices, and Exchange Rates." Essays in History 34, 1992. Calomiris, Charles W., "Institutional Failure, Monetary Scarcity, and the Depreciation of the Continental." Journal of Economic History, March 1988, 48 (1), pp. 47 - 68. 
Cole, Arthur H., Wholesale Commodity Prices in the United States, 1700-1861: Statistical Supplement, Actual Wholesale Prices of Various Commodities. Cambridge, MA: Harvard University Press, 1938.

Ferguson, E. James, "Currency Finance: An Interpretation of Colonial Monetary Practices." William and Mary Quarterly, 1953, pp. 153 - 180.

Grubb, Farley, "Creating the U.S. Dollar Currency Union, 1748-1811: A Quest for Monetary Stability or a Usurpation of State Sovereignty for Personal Gain?" American Economic Review, December 2003, 93 (5), pp. 1778 - 1798.

Johansen, Soren. "Estimation and Hypothesis Testing of Cointegration Vectors in Gaussian Vector Autoregressive Models." Econometrica, November 1991, 59 (6), pp. 1551 - 1580.

Levine, Ross, and Robert G. King. "Finance and Growth: Schumpeter Might Be Right." Quarterly Journal of Economics, August 1997, 108 (3), pp. 717 - 738.

Levine, Ross, and Sara Zervos. "Banks, Stock Markets, and Economic Growth." American Economic Review, June 1998, 88 (3), pp. 537 - 558.

McCusker, John J. Money and Exchange in Europe and America, 1600-1775: A Handbook. Chapel Hill, NC: University of North Carolina Press, 1978.

Michener, Ron. "Money in the American Colonies." EH.Net Encyclopedia, Robert Whaples, ed., 2003, URL http://www.eh.net/encyclopedia/contents/michener.american.colonies.money.php.

Michener, Ron, and Robert E. Wright. "State 'Currencies' and the Transition to the Dollar: Clarifying Some Confusions.” Manuscript, NYU and the University of Virginia, 2003. Perkins, Edwin J. American Public Finance and Financial Services, 1700-1815. Columbus, OH: Ohio State University Press, 1994.

Rothenberg, Winifred. "The Emergence of a Capital Market in Rural Massachusetts, 1730-1838." 
Journal of Economic History, 1985, 85, pp. 781 - 808.

Rousseau, Peter L., and Richard Sylla. "Emerging Financial Markets and Early U.S. Growth." Explorations in Economic History October 2004 [Previously published as Working Paper No. 7448, National Bureau of Economic Research, December 1999].

Rousseau, Peter L., and Richard Sylla. "Financial Systems, Economic Growth, and Globalization." In M. Bordo, A. Taylor, and J. Williamson, eds., Globalization in Historical Perspective. Chicago: University of Chicago Press, 2003, pp. 373-413.

Rousseau, Peter L., and Paul Wachtel. "Financial Intermediation and Economic Performance: Historical Evidence from Five Industrialized Economies." Journal of Money, Credit and Banking, November 1998, 30 (4), pp. 655 - 673.

Rousseau, Peter L., and Paul Wachtel. "Equity Markets and Growth: Cross Country Evidence on Timing and Outcomes, 1980-1995." Journal of Banking and Finance, December 2000, 24 (12), pp. 1933 - 1957.

Sims, Christopher A., James H. Stock, and Mark W. Watson. "Inference in Time Series Models With Some Unit Roots.” Econometrica, January 1990, 58 (1), pp. 113 - 144.

Sylla, Richard. "U.S. Securities Markets and the Banking System, 1790-1840." Federal Reserve Bank of St. Louis Review, May/June 1998, 80, pp. 83 - 98.

Temin, Peter. The Jacksonian Economy. New York: W. W. Norton and Company, 1969.

U.S. Bureau of the Census. Historical Statistics of the United States: from Colonial Times to 1970. Washington, DC: Government Printing Office, 1975.

Wright, Robert E. Origins of Commercial Banking in America, 1750-1800. London and New York: Rowman and Littlefield, 2001. 